\title{
Perceived Influence of Socio-economic Factors of Fadama III Farmers on Forest Resources Values in Benue State, Nigeria
}

\author{
Dagba, B. I ${ }^{1}$., Igbaukum, $E^{2}$., Ancha,P.U ${ }^{1}$. and Ikyaagba, E.T ${ }^{1}$. \\ ${ }^{1 .}$ Department of Social and Environmental Forestry, University of Agriculture, Makurdi, Nigeria. \\ 2. Benue State Value Chain Development Programme, BNARDA Head Quarters Makurdi, Benue State
}

\begin{abstract}
It is believed that several socio-economic factors influence rural people's utilization, depletion and conservation of forest resources. There is a growing wealth of information available on the utilization and contributions of forest resources to rural livelihoods in Benue State. However, these studies failure to consider socio-economic factors influencing farmers' perception of forest resources values in Benue State. A better understanding of farmers' knowledge of the value forest resources is fundamental to sustainable management perceived values. . Therefore, this paper assessed factors influencing FADAMA III user Groups (FUGs) perceived value of forest resources in Benue State. The population of the study comprised of crops User groups of FADAMA III in the study area. Sample sizes of 734 respondents were selected using stratified, purposive sampling technique. Primary data were collected through the use of semi-structured questionnaire. Descriptive and inferential statistical methods were used to analyze the quantitative data. Binary Logistic Regression Analysis was used to determine the factors influencing respondents' perceived values of forest resources. The results of the study revealed that majority of the respondents (83.5\%), were male. The average age of the respondent was $44 \pm 8.154 S D$ with most of the respondent (46.0\%) having Non-formal education, the mean annual income of the respondents was 570,000 $\pm 374,005.82 S D$. The average land occupied by FADAMA III projects in the area was 1.86 \pm 0.942 . Period of residence (Exp B) 1.20 was the most important variable influencing respondents perceived values of forest resources. Sex of the respondents in the study area had a negative regression coefficient $(\beta)$ of -0.10 with odds ratio $\operatorname{Exp}(\beta)$ of 0.90 , Years spent in formal school had non-significant negative influence on respondent's perceived values of forest resources in the study area. The $(\beta)$ coefficient was -0.03 with odds ratio $\operatorname{Exp}(\beta)$ of 0.97. It was recommended that Farmers in the study area be educated more on the environmental values of trees which can enhance conservation among the farmers.
\end{abstract}

\section{Introduction}

Forest products play important roles in supporting rural livelihoods and food security in many developing countries. Forests provide critical sources of food, medicine, shelter, building materials, fuels and cash income. More than 15 million people in Sub-Sahara Africa earn their income from forest-related enterprises such as firewood and charcoal sales, small-scale saw-milling, commercial hunting and handicraft production (Kaimowtz, 2003).

In recent years, there has been increasing interest in the contributions that forests make as a source of local rural livelihood. This stems from arguments that the contribution is important in terms of both rural livelihoods and sustainable forest management. Studies on non-farm rural employment and income has shown that production and trading activities in forest products constitute one of the largest parts of rural non-farm enterprise in developing countries (Liedholm and Mead, 1993). According to Duong (2008) Forest-based activities in developing countries provide an equivalent of 17 and 30 million full-time jobs in the formal and informal sector respectively, as well as $13-35 \%$ of all rural non-farm employment. It is established that harvesting of forest products is undertaken by farmers (Arnold and Townson, 1998) and conservation of the forest resources is based on their values.

In Nigeria there is a growing wealth of information available on the contribution of forest resources to rural livelihood (Aiyeloja and Ajewole, 2006; Jimoh, 2006; Adekunle et al., 2011; Onuche, 2011; Chukwuone and Okeke, 2012, Iheke and Eziuche, 2016). In Benue State, studies (Tee et al., 2009; 2014; Ikoni, 2012; Adagba et al., 2016; Shomkegh et al., 2016) have shown that farmers often use a diverse variety of forest products; they also know a good number of forest species (Agbidye et al., 2014). Agbidye et al., (2014) further stated that farmers in the state even have good knowledge of when plants start flowering and fruiting including even their pollination agents. These studies indicate that, there is a knowledge gap on the socio-economic factors influencing farmers' perception of forest resources values in Benue State. It is believed that several socio-economic factors influence rural people's utilization, depletion and conservation of forest resources (Schwartz and Caro 2003, Giliba et al., 2011). A better understanding of rural people's knowledge of the forest, their awareness of forest resources and their perceived values on their socio-economic and environmental welfare is fundamental to the development and implementation of management strategies that are both 
sustainable in the long term and sensitive to existing local needs. Therefore, this paper assessed factors influencing FADAMA III user Groups (FUGs) perceived value of forest resources in Benue State. It is believed that the information generated in this study will help decision makers and other stakeholders in promoting sustainable forest resources management.

\section{Study Area}

Benue State is located within Middle Belt of Nigeria on Longitude $6^{\circ} 31^{\prime} \mathrm{E}$ and $10^{\circ} \mathrm{E}$ and between Latitudes $6^{0} 30^{\prime} \mathrm{N}$ and $8^{\circ} 10^{\prime} \mathrm{N}$ and the land mass of 33,955km2 (BNARDA, 2005). The State has a population of approximately 5 million by 2009 estimate/projection based on a $2.8 \%$ growth rate (NPC, 2006). Benue State has 23 Local Government Areas as contained in Fig 1.

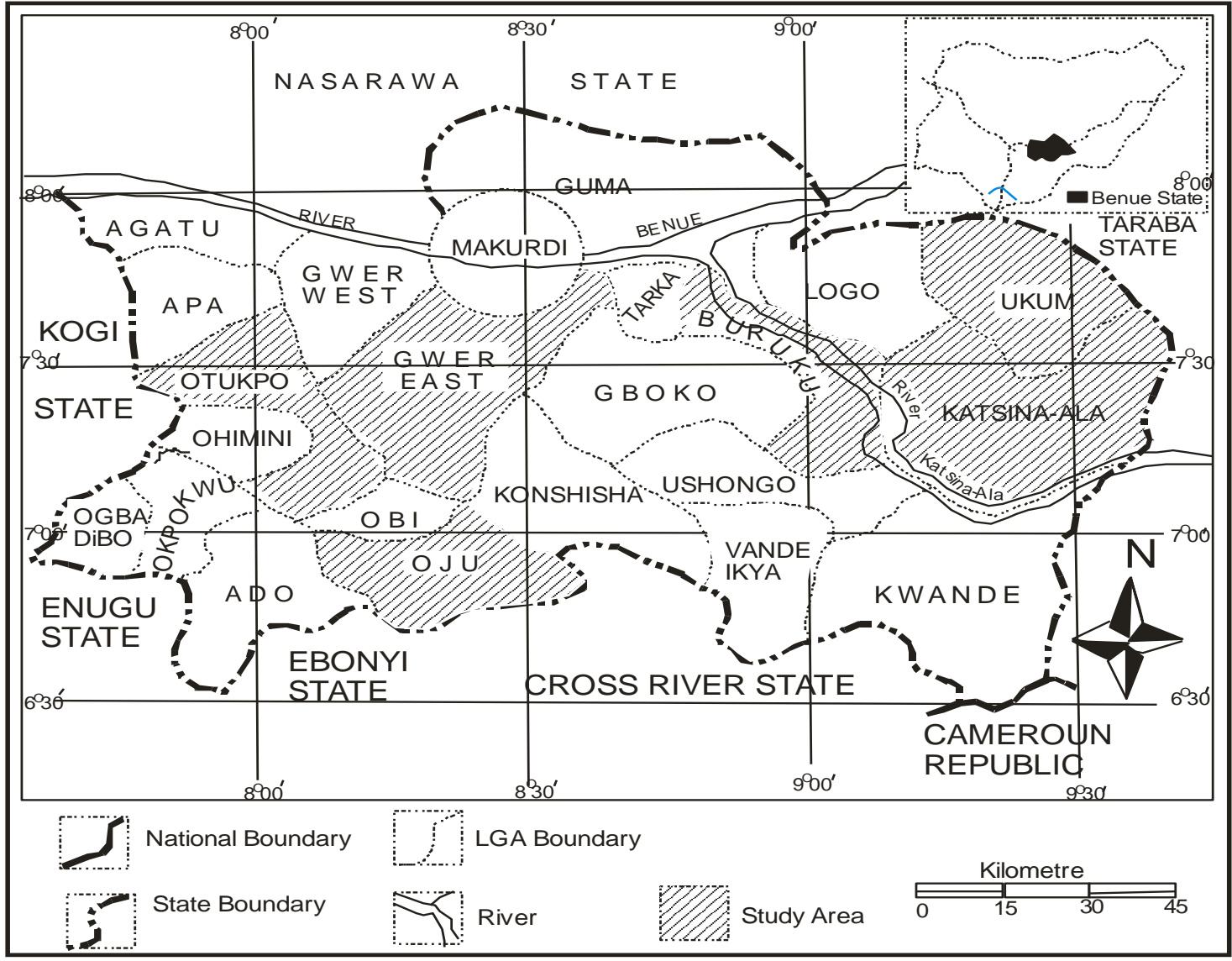

Fig 1. Map of Benue State showing study areas

Source: Ministry of Lands and Survey Makurdi (2015).

\section{Climate}

Benue State experiences two distinct seasons, the wet and the dry season. The rainy season lasts from April to October with annual rainfall in the range of $1000-2000 \mathrm{~mm}$. The dry season begins in November and ends in March. Temperatures fluctuate between 21 - 37 degrees Celsius in the year. The south-eastern part of the State adjoining the Obudu-Cameroun mountain range, however, has a cooler climate similar to that of the Jos Plateau State (Adamgbe and Ujoh, 2012).

\section{Vegetation}

The vegetation in these areas in the State is open savannah woodland, characterized by predominantly fewer trees, more shrubs and predominantly tall grasses up to $2 \mathrm{~m}$ tall. Forest formations are found in low land areas and river banks. Some of the species found in the area include; Daniellia oliveri, Vitelleria paradoxa, Vitex doniana, Hymenocordia acida, Burkia africana, Khaya senegslensis, Parkia biglobosa among others (Jimoh, et al., 2009).

\section{Topography}

The elevation which is generally undulating rises from the Benue valley below $100 \mathrm{~m}$ Eastwards and Southwards to the Western ranges of Cameroonian highlands and Nsukka escarpments respectively (Adamgbe 
and Ujoh, 2012). Benue State is drained by River Benue and its tributaries such as Katsina-Ala, Okpokwu, Guma, Gwer, and Aya. The dominant soil in the State is the tropical ferruginous which is generally low in organic matter, bases and cation exchange capacity (Adamgbe and Ujoh, 2012)

\section{Population, Sampling Procedure and Sample Size}

The population of the study is made up of all the User groups in the study area. The target groups in the study were members of FUGs. There were between 10-15 FUGs in each Fadama Community Association (FCA), (Benue FADAMA III COMPENDIUM, 2014). Each FUG has between 10-25 members and 734 members (Table1) were drawn to form the study size. Stratified and purposive sampling techniques were adopted for the study.

The State was stratified into three parts based on the existing senatorial zones. In each zone, $20 \%$ of FUGs were sampled purposively based on the sub-projects which had bearing on forest resources. In each FUG 2 members were purposively selected based on their knowledge of the sub-project.

Table 1. Summary of Sampling Procedure of the Study

\begin{tabular}{|l|l|l|l|l|}
\hline Senatorial & No. Of & No. Of & 20\% of & 2 Respondents Selected \\
\hline Zone & FCA & FUGs & FUGs & in each FUG \\
\hline A & 49 & 682 & 136 & 272 \\
\hline B & 41 & 470 & 94 & 188 \\
\hline C & 44 & 685 & 137 & 274 \\
\hline Total & 152 & 1857 & 367 & 734 \\
\hline
\end{tabular}

\section{Data collection}

The study made use of both the primary and secondary data. Primary data was collected through the use of questionnaire while secondary data was obtained from the Fadama State Office records. Direct observations were made to assess the current status of forest resources around Fadama projects.

\section{Data Analysis}

Both descriptive and inferential statistical methods were used to analyze the quantitative data. Descriptive statistics such as frequency and percentages were used to analyze socio-economic characteristics of the respondents. They were also used to analyze the forest resources available in the area.

Binary Logistic Regression (BLR) analysis was used to determine the factors influencing respondents' perceived forest resources values in the study area

\section{Socio-economic Characteristic of the Respondents}

\section{Result}

The socio-economic characteristic of the respondents as shown in Table 2 revealed that $16.5 \%$ of the respondents were females while $83.5 \%$ were males. The mean age of the respondents was 44years. In terms of education $46 \%$ of the respondents' had non-formal education, $18.7 \%$ had primary education, and $20.7 \%$ had secondary education, while those with tertiary were the least $14.6 \%$. All the respondents interviewed were married, also all the respondents were farmers. The result also showed that $43.1 \%$ of the respondents earned between N401, 000-N800, 000 annually with the mean annual income value of $\$ 570,000$. The result also showed that $42.3 \%$ of the respondents were in the area for a period of between 41-50 years with average period of stay of $44.10 y e a r s$. Majority of the respondents $(89.0 \%)$ normally cultivate between $1-3$ ha, $10.8 \%$ cultivated between 4-6ha while $0.3 \%$ cultivated between 7-9ha annually, the mean annual farm size cultivated by respondents was $2.32 \mathrm{ha} \mathrm{per} \mathrm{year.}$

Table 2: Socio economic Characteristics of the Fadama User Groups in Benue State

\begin{tabular}{|l|l|l|}
\hline Sex & Frequency $(\mathrm{n}=734)$ & Percent $(\%)$ \\
\hline Female & 121 & 16.5 \\
\hline Male & 613 & 83.5 \\
\hline Age years & & \\
\hline $30-40$ & 273 & 37.2 \\
\hline $41-50$ & 311 & 42.4 \\
\hline $51-60$ & 123 & 16.8 \\
\hline $61-70$ & 24 & 3.3 \\
\hline $71-80$ & 3 & 0.4 \\
\hline Mean age & $44 \pm 8.154$ SD & \\
\hline Educational Status & & \\
\hline Non-Formal Education & 338 & 46.0 \\
\hline Primary Education & 137 & 18.7 \\
\hline Secondary Education & 152 & 20.7 \\
\hline
\end{tabular}


Perceived influence of socio-economic factors of fadama iii farmers on forest resources values in ..

$\mathrm{SD}=$ Standard Deviation

\begin{tabular}{|l|l|l|}
\hline Tertiary Education & 107 & 14.6 \\
\hline Marital Status & & \\
\hline Married & 734 & 100.0 \\
\hline Occupation & & \\
\hline Farming & 734 & 100.0 \\
\hline Annual income (N) thousand & & \\
\hline $50,000-400,000$ & 274 & 37.3 \\
\hline $401,000-800,000$ & 316 & 43.1 \\
\hline $801,000-1,200,000$ & 103 & 14.0 \\
\hline $1,201,000-1,600,000$ & 34 & 4.6 \\
\hline $1,601,000-2,000,000$ & 2 & 0.3 \\
\hline $2,001,000-2,400,000$ & 1 & 0.1 \\
\hline $2,401,000-2,800,000$ & 4 & 0.5 \\
\hline Mean income & $570,000 \pm 374,005.82$ SD & \\
\hline Period of Residence (Years) & & \\
\hline $30-40$ & 273 & 37.2 \\
\hline $41-50$ & 311 & 42.4 \\
\hline $51-60$ & 123 & 16.8 \\
\hline $61-70$ & 24 & 3.3 \\
\hline $71-80$ & 3 & 0.4 \\
\hline Mean Period of Residence & $44 \pm 8.138$ SD & \\
\hline Farm size (ha) & & \\
\hline $1-3$ & 653 & 89.0 \\
\hline $4-6$ & 79 & 10.8 \\
\hline $3-9$ & 2 & 0.3 \\
\hline Mean Farm size (ha) & $2.32 \pm 1.037$ SD & \\
\hline & & \\
\hline
\end{tabular}

\section{Values of Forest Resources and Contribution to Livelihood in the Area}

Majority of the respondents $(99.0 \%)$ agreed that forests have value in their locality, as indicated in Table 3; they listed six common uses of forest resources in the area. The result also showed that fuel wood was the highest $(47.0 \%)$ benefit derived from forest resources in the study area. Also majority of the respondents $(94.8 \%)$ indicated that forest resources in the area have been contributing to their livelihood.

Table 3. Respondents Response to Questions on Values of Forest Resources and Contribution to Livelihood in Benue State

\begin{tabular}{|l|l|l|l|}
\hline Question & Response Category & Frequency $(\mathbf{n = 7 3 4 )}$ & $\mathbf{\%}$ \\
\hline Do the forest resources have any value to you & Yes & 7 & 1.0 \\
\hline & No & 727 & 99.0 \\
\hline Various uses of forest resources in the area & Source of Food & 77 & 11.1 \\
\hline & Source of Meat & 9 & 1.2 \\
\hline & Fuel-wood & 347 & 47.0 \\
\hline & Medicare & 66 & 9.0 \\
\hline & Timber material & 215 & 29.0 \\
\hline & Animal feeds & 20 & 2.7 \\
\hline Do forest resources contribute to your livelihood & No & 38 & 5.2 \\
\hline & Yes & 696 & 94.8 \\
\hline
\end{tabular}

\section{Factors Influencing Respondents Perceived Forest Resources Values in the Study Area}

The result presented in Table 4 showed that all Wald statistics were non-zero values, which implied that there was interaction between the dependent (Perception of forest resources values) and independent variables; indicating the presence of relationships between the dependent and independent variables (Giliba et al., 2011).

Sex of the respondents in the study area had a negative regression coefficient $(\beta)$ of -0.10 with odds ratio $\operatorname{Exp}(\beta)$ of 0.90 , indicating that a unit increase in the number of female respondents will decrease the likelihood of perceiving values of forest resources by factor 0.90 and vice versa. The variable was not statistically significant $(\mathrm{p}>0.05)$. The male respondents were the variable of interest in the analysis.

Income of the respondents in the study area had a non-significant positive regression coefficient $(\beta)$ of 0.00 with odds ratio $\operatorname{Exp}(\beta)$ of 1.000 which indicates that a unit increase in income will increase the likelihood of perception of values of forest resources by a factor 1.000 and vice versa.

Duration of residence in the area had a non-positive regression coefficient $(\beta)$ of 0.18 with odds ratio $\operatorname{Exp}(\beta)$ of 1.20. This indicates that the chance of perception of values of forest resources will increase by a factor of 1.20 for a unit increase in the period of stay in the area. In other words, increase in the number of years of residence of the respondents in the study area increases the likelihood of perceiving the values of forest resources in the area. 
Perceived influence of socio-economic factors of fadama iii farmers on forest resources values in ..

Years spent in formal school had non-significant negative influence on respondent's perceived values of forest resources in the study area. The $(\beta)$ coefficient was -0.03 with odds ratio $\operatorname{Exp}(\beta)$ of 0.97 indicating that increase in the years of schooling will lead to a decrease in likelihood of perceiving the values on forest resources in the study area by a factor 0.97 .

Age of the respondents had a non-significant positive $(p>0.05)$ influence on the respondents perception. The regression coefficient $(\beta)$ of 0.11 with odds ratio $\operatorname{Exp}(\beta)$ of 1.11 indicated that a unit increase in age will lead to an increase in the likelihood of perceiving the values of forest resources by a factor of 1.11 .

Table 4. Logistic Regression Analysis of Socio economic Factors Influencing Respondents perception of Forest Resources Values in the Benue State

\begin{tabular}{|l|l|l|l|l|l|l|}
\hline Variables & B & SE & Wald & Df & Sig & EXP(B) \\
\hline $\mathrm{X}_{1}=$ sex & -0.10 & 1.09 & 0.009 & 1 & 0.92 & 0.90 \\
\hline $\mathrm{X}_{2}=$ age & 0.11 & 0.18 & 0.978 & 1 & 0.950 & 1.11 \\
\hline $\mathrm{X}_{3}=$ Schooling years & -0.03 & 0.06 & 0.186 & 1 & 0.67 & 0.97 \\
\hline $\mathrm{X}_{4}=$ income & 0.000 & 0.000 & 0.001 & 1 & 0.98 & 1.000 \\
\hline $\mathrm{X}_{5}=$ period & 0.18 & 2.14 & 0.07 & 1 & 0.93 & 1.20 \\
\hline Constant & 2.53 & 2.61 & 0.94 & 1 & 0.33 & 12.61 \\
\hline
\end{tabular}

$\mathrm{P}=0.68$

Number of cases $=734$, Model Chi-square $=9.24(p>0.05),-2 \mathrm{LL}=77.53$; Overall percentage $=99 \%, \operatorname{Exp}(\beta)=$ odds ratio (probability of success/probability of failure), $\mathrm{SE}=$ standard error of the estimate, $\mathrm{Sig}=$ significance, $\mathrm{b}$ $=$ regression coefficients which stand for the odds ratio of probability of success to the probability of failure and Wald statistics $=(\mathrm{b} / \mathrm{SE})^{2}$, d.f $=$ degree of freedom

\section{Discussion}

\section{Socio-economic Characteristics of the Respondents Participating in FADAMA Activities in Benue State}

The study recorded more male than their female counterpart in FADAMA activities in the study area, even though FADAMA project as a World Bank Project has a special consideration for women particularly widows and divorced (Umar, 2007; Mohammed et al., 2011). Similar situation were reported in Kwara State (Babatunde et al., 2008) and in Niger State (Mohammed et al., 2011) where women participation was low. This low participation could be due to the nature of the crops involved. For instance in Edo State Omorogbee and Onemolease (2008) reported that women were the dominant participant in FADAMA activities, which they linked to the type of crop, cultivated mostly vegetables.

The low participation of youth in the project was an indication that young people are gradually leaving agriculture, even with the presence of incentives. Similar situation was reported by Mohammed et al. (2011) in Niger State and Omorogbee and Onemolease (2008) in Edo State. However Adeolu et al. (2004) considered this age group of above 40 years which dominated the program as not healthy. Their submission was that, it was an indication that the youth were not replacing the older ones or the youth were not getting involved in Agricultural activities. On the conservation side the reduced involvement of youth may be of benefit as it would reduce pressure on forest resources (Ajake and Enang, 2012).

It was clear from the study that agriculture in Benue State and indeed Nigeria is still left in the hands of uneducated people (Adeolu et al., 2004). This might explain why adaptation of sustainable agriculture which is environmentally friendly might be difficult to achieve in Nigeria. This could be due to the fact that most educated young people are not ready to take to farm activities as observed by Adeolu et al. (2004) but rather prefer to migrate to urban areas for greener pastures. Muhammad et al. (2011) reported the same experience in Niger State, where most of FADAMA participants had below primary education. In Kwara State, Babatunde et al. (2008) found that over $60 \%$ of farmers of Fadama II Maize FUGs had no formal education. The result of the study also demonstrated that farmers in the area usually have low income from their farm produce which is the major attributes of farming in sub Saharan Africa (Oni, 2014), which in most cases is due to poor farm yield. The small size of project might be due to the nature of land tenure in the area which makes it difficult to acquire land on large scale; this agreed with the finding of Adeolu et al. (2004) and Babatude et al. (2008).

\section{Values of Forest Resources}

Throughout the history of man, forest resources have been important to human being (Young and Giese, 2003). This was clearly demonstrated in this study. The result of the study revealed that a good numbers of people in the area were knowledgeable about uses of plant around them and they perceived trees as being valuable and useful resources. This agreed with the finding of Agbidye et al. (2014). This knowledge was reflected by the number of uses they were able to mention and it was a manifestation that trees formed an integral part of their daily life. Similar experience was reported by Kobbail (2012) in Kosti province of White Nile area of Central Sudan. The values of the forest resources mentioned in this study were similar to the ones mentioned by other studies (Jimoh et al., 2009; Onuche, 2010; Ramcilovic-Suominen et al., 2012; Yang et al., 
Perceived influence of socio-economic factors of fadama iii farmers on forest resources values in ..

2015). The study revealed further that FADAMA III user group members appeared to be mostly concerned about the economic values that are directly connected to their livelihoods. Similar experiences were recorded by Yang et al. (2015) in southern China and Arowosoge (2015) in Ekiti State Nigeria. This according to Ramcilovic-Suominen et al., (2012), a farmer is primarily interested in using forests for commercial use, to improve their economic well-being rather than other benefits like for the provision of environmental services (e.g. climate regulation, erosion control and biodiversity conservation).

The study established that fuel wood still remained the major source of energy in Benue State like other parts of Nigeria. This confirmed the submission by Ogunjinmi et al.(2008) and Onuche (2010) that fuel wood constitutes the major forest products from savanna vegetation as it accounts for a larger part of household energy need and meeting $80 \%$ of domestic energy requirement of rural and urban people in Nigeria. This high dependence could be linked to the high cost of other forms of energy which are usually beyond the reach of the poor, thereby forcing them to rely more on fuel wood for their energy need. The implication of this high rate of fuel wood consumption is that, there will be increase in forest resources depletion.

\section{Factors Influencing Respondents Perception of Forest Resources Values in the study Area}

It was evident from the study that socio-economic variables of the respondents like age, period of residence and income had positive association with respondents perceived values of forest resources, though the regression coefficients of these variables were not significant at $(\mathrm{P}<0.05)$. The positive regression implies that elderly people perceived more forest resource values than the younger which could be due to the fact that the older generation has had more experience, longer association and interaction with forest resources (Yang et al., 2015). This agreed with submission by Hunter (2007) that experience changes peoples' values of forest resources. Similar experience was observed by Yang et al. (2015) in Southern China that age lead to a reduction of the difference in perception of the number of forest values between older and younger people. Another possible explanation was attributed to the fact that the young people have more opportunities to leave the community and gain more in-depth environmental education or have more frequent contact with the outside world through various media sources (Yang et al., 2015). The implication of this finding could be an indication of loss of traditional knowledge about tree values among the young generation (Jimoh et al., 2009)

The study has demonstrated that most of the educated people were youth with low knowledge about the uses of plants around them. This could be the possible reason for negative regression coefficient for education, as their education did not translate into knowledge about trees uses. However, elderly people who had good knowledge about the uses of forest resources were uneducated. This was evidenced in the positive association with age. Similar findings were reported by Luoga et al. (2000) in Kitulanghalo, Tanzania. This study also agreed with submissions by Hunter (2007) that acquiring more education is not the simple solution to change people's values of forest resources. In this light, Caro et al. (2003) considered the type of education one has to be the solution in changing his view and value system. Caro et al. (2003) study revealed that people with environmental education were more concerned about conservation. Another reason might be that highlyeducated people will have greater off farm employment opportunities than less educated people which will take them away from forest environment (Adhikari et al,. 2004). In general, education creates more and better employment opportunities and reduces dependent on forest resources for survival. However, the no significant value $(r=-0.022, p>0.057)$ suggested that no matter the level of one's education he /she still had value for forest resources.

It is believed that use of forest resources depended on the sex of the individual. Studies have shown that the roles, knowledge, and skills of rural men and women differ with respect to forest use and management (Hunter, 2007; Agarwal, 2009; Mai et al.2011 Sunderland et al., 2014). The negative relationship ( $\mathrm{r}=-0,006$, $\mathrm{p}>0.057$ ) was an indication that males and females in the study area valued forest resources in different ways. This agreed with findings of Hunter (2007) that men and women differ in how they value particular species because they interact with different suites of species. According to Sunderland et al. (2014) Activities along the forestry value chain tend to be differentiated along gender lines. These differences may be connected to the types of forest products collected by both men and women (Sunderland et al., 2014) .

Increase in the number of years of residence of the people in the study area increases the likelihood of perception of forest resources values. The more people stay in a given place, the more their familiarity with forest resources in the area and their benefits (Shibia, 2010). Hunter (2007) stated that experience is the major factor that influences and changes people's values and attitudes towards forest resources, their uses and conservation. This is because older people and those who stay in the area a long time might have good knowledge of how the vegetation was and will be able to detect changes in the vegetation cover.

The positive association between income and forest resources values in the study area was confirmation of submission by other studies that higher incomes, of rural poor in developing countries, are likely to increase the dependency on forests (Angelsen and Kaimowitz, 1999; Escobal and Aldana, 2003; Adhikari et al., 2004; 
Perceived influence of socio-economic factors of fadama iii farmers on forest resources values in ..

Mamo et al., 2007). It was clear that most of the incomes were coming from the selling of NTFPs such as fuel wood as it was evidence with high percentage for fuel wood as major forest resources.

This study agreed with submission by Coulibaly- Lingani et al. (2009) that ownership of more assets allows households to exploit more forest resources. This implies that forest products play an important role in equalizing incomes of rural households, as well as in sustaining the livelihood of the rural poor and in managing risks associated with weather, crop losses and other unpredictable events (Coulibaly- Lingani et al., 2009).

\section{Conclusions And Recommendation}

This study provides an understanding of FADAMA III User groups' perceptions of value of forest resources. The result of the study revealed that good numbers of people in the area were knowledgeable about uses of plant around them and they perceived trees as being valuable and useful resources. The study also confirmed high dependence on forest resources in the area especially fuel wood; the implication of this high rate of fuel wood consumption is that, there will be increase in forest resources depletion.

Members of FADAMA III User groups' understood values of forests, but the understanding was influenced by socio-economic factors of sex, age, education, income and period of resident. While socioeconomic variables of the respondents like age, period of residence and income had positive association with respondents' perceived values of forest resources, sex and education had negative influence on their perceived values of forest resources. This meant that forest resources value chain differentiated along gender lines and also not the level of education but the types of education one had that influenced his value and perception of forest resources. It was recommended that Farmers in the study area be educated more on the environmental values of trees which can enhance it conservation among the farmers.

\section{Reference}

[1]. Adagba, M. N., Shomkegh, S.A. and Ikyaagba, E. T (2016). Relative Abundance and Local Uses of Wild Trees Species in Ukohol Community, Guma Local Government Area of Benue State, Nigeria. Journal of Environmental Science, Toxicology and Food Technology 10( 8): 18-24

[2]. Adamgbe, E.M. and Ujoh, F. (2012). Variations in Climatic Parameters and Food Crop Yields: Implications on Food Security in Benue State, Nigeria. Confluence Journal of Environmental Studies7:59-67

[3]. Adeolu, B.A. and Taiwo, A.(2004), 'The Impact of National Fadama Facility in Alleviating Rural Poverty andEnhancing Agricultural Development in South-Western Nigeria'. Journal of Social Science, 9(3).

[4]. Adhikari, B., Falco, F.D. and Lovett, J.C . (2004) Household characteristics and forest dependency: evidence from common property forest management in Nepal. Ecological Economics 48 245-257

[5]. Agarwal, B. (2009) Gender and forest conservation: The impact of women's participation in community forest governance Ecological Economics, 68: 2785-2799

[6]. Agbidye, F.S., Tee, F.C. and Ogwuche J.A. (2014). Use of Some Indigenous Forestry Knowledge in Managing Forest Resources in Selected Local Government Areas, Benue State, Nigeria. Applied Tropical Agriculture 19 ( 1) 66 - 70

[7]. Aiyeloja, A. A. and Ajewole, O.I. 2006. Non-timber forest products' marketing in Nigeria. A case study of Osun state. Educational Research and Reviews 1 (2): 52-58,

[8]. Ajake, A.O. and Enang, E.E. (2012) Demographic and Socio-Economic Attributes Affecting Forest Ecosystem Exploitation and Management in The Rural Communities of Cross River State, Nigeria. American International Journal of Contemporary Research 2 (1) $174-184$

[9]. Angelsen, A., Kaimowitz, D., 1999. Rethinking the causes of deforestation: lessons from economic models. The World Bank Research Observer, 14, 73-98.

[10]. Arnold, M. and Townson, I. (1998). Assessing the Potential of Forest Product activities to Contribute to Rural Incomes in Africa ODI Natural Resource Perspectives Number 37, November 1998

[11]. Arowosoge, O. G. (2015).Local People's Perception of Forest Resources Conservation in Ekiti State, Nigeria. Journal of Environmental Science and Engineering B 4 132-140 doi:10.17265/2162-5263/2015.03.004

[12]. Babatunde, R .O., Fakayode, S.B and Obafemi, A.A. (2008) Fadama Maize Production in Nigeria: Case Study from Kwara State. Research Journal of Agriculture and Biological Sciences, 4(5): 340-345

[13]. Chukwuone, N.A. and Okeke, C.A. (2012). Can non-wood forest products be used in promoting household food security?: Evidence from savannah and rain forest regions of Southern Nigeria, Forest Policy and Economics (2012), http://dx.doi.org/10.1016/j.forpol.2012.09.001

[14]. Coulibaly-Lingani, P,, M Tigabu, M., Savadogo, P., Oden, P. and Ouadba, J. (2009) Determinants of access to forest products in southern Burkina Faso. Forest Policy and Economics 11 516-524

[15]. Duong, N.H. (2008). The role of non timber forest products in livelihood strategies and household economics in a remote upland village in the upper ca river basin, nghe the Phuong. Journal of Science and Development: 88-98.

[16]. Escobal, J., Aldana, U., 2003. Are non-timber forest products the antidote to rainforest degradation? Brazil nut extraction in Madre De Dios, Peru.World Development, 31, 1873-1887.

[17]. Giliba, R. A., Boon, E. K., Kayombo, C. J., Chirenje, L. I. and Musamba, E.B. The Influence of Socio- economic Factors on Deforestation: A Case Study of the Bereku Forest Reserve in Tanzania. Journal Biodiversity,2(1): 31-39

[18]. Hunter, Jr. M.L. and Gibbs, J.P. (2007). Fundamentals of Conservation Biology. Third Edition, Blackwell Publishing, Malden, USA. 515pp

[19]. Iheke, O. R. and Eziuche, A. O. (2016) Forest Resources Exploitation and its Implications on Rural Agro-Economy in Isiala Ngwa North Local Government Area of Abia State, Nigeria. Nigerian Journal of Agriculture, Food and Environment. 12(1):37-43

[20]. Ikoni, U. D. (2012). Patterns and Trends in the Use of Protected Forest Resources among Rural Agricultural Communities in Benue State: Challenges and Legal Implications for SustainableDevelopment .The Asian Conference on Sustainability, Energy \& the Environment Official Conference Proceedings Osaka, Japan, 2012 263-296pp 
[21]. Jimoh, S. O. 2006. Sustaining the Roles of Non-Timber Forest Product in Rural Poverty Reduction and Household Food Security. Journal of Fisheries International 2 (4): 63- 69.

[22]. Jimoh, S.O., Adebisi,L.A and Ikyaagba E.T. (2009). Biodiversity and ethnobotanical potentials of plant species of University of Agriculture Makurdi Wildlife Park and Ikwe Games Reserve, Benue State, Nigeria. Int. J. Biol. Chem. Sci., 3 (6):1375-1385

[23]. Kaimowitz, D. 2003. Not by Bread Alone ... Forests and Rural Livelihood in Sub- Saharan Africa. In Oskanen, T., Pajari, B. and Tuomasjukka, T. (eds.): Forest In Poverty Reduction Strategies: Capturing the Potential, EFI Proceedings No. 47. European Forest Institute: Joensuu, Finland p. 7-15.

[24]. Kobbail, A. A. (2012). Local People Attitudes towards Community Forestry Practices: A Case Study of Kosti Province-Central Sudan. International Journal of Forestry Research 1-7 doi:10.1155/2012/652693

[25]. Liedholm, C. and Mead, D.C. (1993) 'The structure and growth of microenterprises in southern and eastern Africa' in 'Growth and Equity through Microenterprise Investments and Institutions (GEMINI) Project' GEMINI Working Paper No. 36. Bethesda: GEMINI

[26]. Luoga, E. J., Witkowski, E. T. F. and Balkwill, K. (2000). Differential utilization and ethnobotany of trees in Kitulanghalo Forest Reserve and Surrounding Communal Lands, Eastern Tanzania. Economic Botany 54(3): 328-343.

[27]. Mai, Y.H., Mwangi, E. and Wan, M. (2011) Gender analysis in forestry research: Looking back and thinking ahead. International Forestry Review, 13 (2): 245-258

[28]. Mamo, G., Sjaastad, E., Vedeld, P., 2007. Economic dependence on forest resources: a case from Dendi District, Ethiopia. Forest Policy and Economics 9, 916-927.

[29]. Muhammad, H.U., Umar, B.F., Abubakar, B. Z. and Abdullahi, A.S. (2011) Assessment of Factors Influencing Beneficiary Participation in Fadama II Project in Niger State, Nigeria. Nigerian Journal of Basic and Applied Science 19 (2): 248-252

[30]. National Population Commission (NPC, 2006) 2006 Population and Housing Census retrieved on 23/4/2016 from http://www.population.gov.ng/

[31]. Ogunjinmi, A.A., Osunsina, I.O.O., Jayeola, O.A. and Ogunjinmi,K.O. (2008). Perception of Environmental Issues by Fuelwood Sellers in Borgu Local Government Area of Niger state, Nigeria. Journal of Environmental Extension 7:43-47

[32]. Omorogbee, F.E. and Onemolease, E. A. (2007). Farmers' Characteristics and Adoption' of Recommended Practices under the Fadama Project Scheme in Edo State, Nigeria Tanzania J. Agric. Sc. 8 (1), $51-56$

[33]. Oni, L.B. (2008) An Assessment of Agriculture and Poverty Reduction Nexus in Nigeria Journal of African Macroeconomic Review 4(1) 265-284

[34]. Onuche, P. 2011. Non-timber forest products (NTFPs): A Pathway for Rural Poverty Reduction in Nigeria. International Journal of Economic Development Research and Investment, 2 (2): 25-34

[35]. Oyugi OJ, Brown SJ, Whelan JC 2007. Effects of human disturbance on composition and structure of Brachystegia woodland in Arabuko-Sokoke Forest. African Journal of Ecology, 46: 374-383

[36]. Ramcilovic-Suominen, S., Matero, J. and Shannon, M. A. Do Forest Values Influence Compliance with Forestry Legislation? The Case of Farmers in the Fringes of Forest Reserves in Ghana. Small-scale Forestry DOI 10.1007/s11842-012-9209-z

[37]. Schwartz MW, Caro TM 2003. Effect of selective logging on trees and understory regeneration in Miombo woodlands. African Journal of Ecology, 41: 75-82

[38]. Shackleton, C. M and Shackleton, S. E. 2006. Household Wealth Status and Natural Resources Use in the Kat River valley South Africa. Ecological Economics 57 (2): 306-317.

[39]. Shibia, M. G. (2010). Determinants of Attitudes and Perceptions on Resource Use and Management of Marsabit National Reserve, Kenya. Journal Human Ecology 30(1): 55-62

[40]. Shomkegh, S. A., Mbakwe R. and Udeagha A. U. (2016) Uses and Relative Abundance of Non-Timber Forest Plants in Farmlands of Selected Tiv Communities in Benue State, Nigeria. Journal of Agriculture and Ecology Research International 8(2): 1-12,

[41]. Sunderland, T., Achdiawan, R., Angelsen, A., Babigumira, R., Ickowitz, A., Paumgarten, F., Reyes-García, V. and Shively, G. 2014. Challenging perceptions about men, women, and forest product use: a global comparative study. World Development 64, (1) S56-S66

[42]. Tee, T. N., Ogwuche, J.A. and Ikyaagba, E.T.(2009). The role of Locust bean and Ironwood Trees in Human Nutrition and Income in Nigeria. Pakistan Journal of Nutrition 8(8) 1172-1177.

[43]. Umar, B.F. (2007). Beneficiary Assessment/ Impact Evaluation in Kebbi State. A draft report. Pp.3-24.

[44]. Yang, H., Harrison, R., Yi, Z., Goodale, E., Zhao, M. and Xu, J. (2015) Changing Perceptions of Forest Value and Attitudes toward Management of a Recently Established Nature Reserve: A Case Study in Southwest China. Forests (6), 3136-3164; doi:10.3390/f6093136

[45]. Young, R.A. and Giese, R.L. (2003). Introduction to Forest Ecosystem Science and Management, Third Edition, John Wiley \& Sons, United States of America 1-589 